\title{
Calculous disease of the vermiform appendix
}

\author{
G. B. FORBES AND R. W. LLOYD-DAVIES
}

From the Kent and Canterbury Hospital, Canterbury

EDITORIAL SYNOPSIS Calculi were found in 29 out of 1,800 vermiform appendices removed at operation. The high incidence of acute complications associated with a calculus indicates the need to remove the appendix when one is found incidentally on radiological examination of the abdomen.

The formation of true calculi within the lumen of the vermiform appendix is a comparatively rare event, but the condition is of clinical importance because of the frequency with which such calculi give rise to serious complications. The main clinico-pathological features of calculous disease of the appendix, based on the examination of 2,000 appendix specimens, are presented in this report with the following objectives in view: to clarify the terminology of the various formed faecal objects which are found in the lumen of the appendix; to assess the incidence of calculous disease and its complications; to draw the attention of surgeons, radiologists, and pathologists to a disease which deserves wider recognition.

\section{DEFINITION OF TERMS}

By reason of its shape and anatomical position, the appendix frequently contains faecal material either as a continuous or interrupted cast of the lumen, or as separate small elliptical faecal masses. When these are formed and hard they are known variously as faecoliths, coproliths, stercoliths, enteroliths, appendicoliths, or concretions. The degree of hardness is a measure of the quantity of calcium in the faecal mass. It is believed that the presence of a small scybalum of inspissated faecal material within the appendix lumen acts as a nucleus around which calcium salts mixed with faecal debris become layered. The calcium salts are derived from mucus excreted in excessive amounts by the appendicular mucosa in response to the local irritant action of the faecal nucleus; in other words a local low-grade catarrhal appendicitis develops. Faecoliths containing a small to moderate amount of calcium are not uncommon; occasionally one will become almost wholly calcified and the stony-hard object which results can fairly be described as a true appendicular calculus. Since gradations of calcification occur, the distinction between calcified faecoliths aud true calculi is arbitrary and indeed the clinical effects and complications of both types of calcified object, whether described as faecolith or calculus, are likely to be very similar. When estimating the incidence of calculous disease, however, it is necessary to have more precise criteria for differentiating the various formed faecal objects encountered in appendicectomy specimens. In the present study all such objects were grouped on the basis of their physical characters, using the following key as an aid to identification:-

1 faECAL Pellet This is a formed, firm, but not calcified, faecal mass. It is brown, smooth, ovoid or cigar-shaped, 'squashable', width equal to or slightly greater than diameter of appendix lumen, and composed of organic material. It is radiotranslucent and very common.

2 CAlCIFIEd Faecolith (FIG. 1a) This is a partially calcified ovoid faecal mass, light or dark brown, moderately hard, crushable rather than squashable, with a slightly granular surface with dark brown or black nodules of calcification, often at the poles. There is patchy laminated radio-opacity, and the width is usually greater than the lumen. It is composed of organic material and a small to moderate amount of calcium phosphate, and is not uncommon.

3 Calculus (FIG. 1b) This is a stony hard, densely radio-opaque object, round, ovoid or irregular in shape, approximately $3 \mathrm{~mm}$. to $3 \mathrm{~cm}$. in main diameter. It is sometimes faceted when multiple, and buff to shiny black in colour, sometimes reddish. It makes a metallic sound when dropped into an enamel or metal vessel, and is composed mainly of calcium phosphate. It is rare.

Nearly all formed faecal objects found in appendices can be placed without difficulty in one of these groups. Sometimes a specimen will prove difficult to 


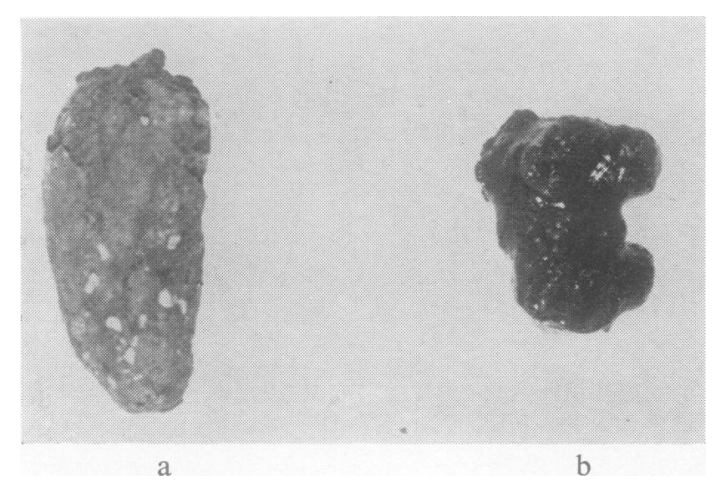

FIG. 1. Calcified faecolith (a) and calculus (b) from case 4.

group because of borderline features, and an added complication is the occasional occurrence of both calcified faecoliths and true calculi in one and the same appendix.

All three types of inclusion may contain radioopaque material in amounts varying from a trace in some faecal pellets to complete dense radio-opacity in the case of true calculi. For this reason we consider that the demonstration of radio-opaque material by straight radiographic examination of the organ after surgical removal is not a reliable guide to the incidence of true calculus formation, at any rate when used as the sole criterion. This technique has been used in some cases by Bowers (1939), Steinert, Hareide, and Christiansen (1943) and more routinely by Felson and Bernhard (1947), Felson (1949), and Shaw (1965), and the frequency with which these authors found radio-opaque objects in acutely inflamed appendices ( 33 to $44 \%$ ) suggests that the test is too sensitive. Indeed Bowers found 'stones' in $25 \%$ of normal appendices. Shaw, using the same technique, found 'calculi' in 79 of 240 inflamed appendices an incidence of $33 \%$, but most of the objects were 'compressible between finger and thumb, fairly soft in consistency and cut easily with a knife'; only occasionally did he find calculi which were firm or hard and demonstrable on radiological examination of the abdomen before operation. Shaw believes that the term 'calculus' should be applied to all objects containing calcium, irrespective of the amount; we find this unacceptable and prefer to apply the term only to an object which fulfils the physical characters of a stone or calculus in the generally-accepted connotation of this term, the main character being stony hardness.

The term 'calculus of the appendix' is used in several reports in the literature to describe objects which were radio-opaque on pre-operative radio- graphs of the abdomen, and yet, after removal, could be cut with a knife (e.g., Candy, 1959). Such radioopaque objects would not qualify for inclusion in the true calculus group as defined above, because of their relatively soft consistence. At the same time one must remember that radio-opaque biliary calculi can sometimes be cut with a knife and no one would suggest that these should be distinguished from gall-stones by labelling them 'calcified choleliths'. It would seem reasonable then to include in the category of true appendicular calculi, calcified faecoliths of sufficient density to be readily detectable on pre-operative radiographic examination of the abdomen.

\section{HISTORICAL}

In 1742 Santorini studied the anatomy of the appendix and his descriptions were accompanied by illustrations of faecal concretions and worms which were found in some of his specimens. Wegeler (1813) used the term 'calculosi concrementi' to describe hard faecal concretions, resembling gall-stones, which he found in the lumen of the appendix. One of the first British surgeons to operate on a patient with acute appendicitis was Hancock (1848); at operation he found that the lumen of the appendix was obstructed by two concretions.

Weisflog (1906) was the first to make a correct preoperative diagnosis of appendicular calculus radiologically. Similar reports came from Fittig (1907) in Germany and Seelig (1908) in America; Seelig admits that he misdiagnosed his case pre-operatively as ureteric calculus. In 1913 Roux wrote a thesis on the diagnosis of appendicitis by radiological methods; he was able to demonstrate foreign bodies and faecal concretions in a number of cases.

A few papers on the subject of appendicular lithiasis appeared in the literature during the period between the world wars, mainly from German sources (see Wells, 1930), and since 1940 some 20 or so papers have been published mainly in American or continental journals. In 1947 Felson and Bernhard estimated that just over 100 cases had been reported; this number had increased to 120 by 1951 (Laforet, Greenler, and O'Brien), and to between 130 and 155 by 1957 (Berg and Berg, 1957; Brady and Carroll, 1957).

About a dozen reports have appeared in British journals, and most of these have dealt with only one or two cases (Wells, 1930, one case; Levi, 1934, one case; Moloney, 1947, one case; Airth, 1948, one case; Chapple, 1951, two cases; Clark, 1952, one case; Smith, 1954, four cases; Atwell and Pollock, 1960, two cases; Butler, 1959, one case; Candy, 1959, two cases; Meyerowitz, 1960, one case; Fox, 1962, one case; and Shaw, 1965, 79 cases). 


\section{INCIDENCE}

GENERAL The frequency with which calculi are found in the appendix can be gauged from incidence figures reported by various authors in this country and abroad (Table I). The data in the upper part of the table refer to cases of calculous disease observed as a result of radiological examination of the abdomen in cases of suspected acute appendicitis. The data in the middle part of the table refer to cases diagnosed by means of radiographic examination of the appendix or calculi after surgical removal. As already stated we consider that these figures give an exaggerated incidence of true calculous disease because the technique used to demonstrate the presence of calcified material is over-sensitive. As acute inflammation is the usual sequel to the presence of a stone in the appendix, it is not surprising that the incidence in this type of material is appreciably higher than that found in routine surgical material. As one might expect, the incidence rates tend to be higher in studies carried out during recent years. Improved diagnostic facilities and standards provide a ready explanation for this trend, in particular the increasing use, especially in America, of 'scout' films as an aid to diagnosis in acute abdominal emergencies. Moreover it is well known that awareness of a disease or condition increases the observed incidence, and higher rates are to be expected in hospitals where radiologists, surgeons, and pathologists are 'calculus conscious'; thus, in one centre in America, 35 cases of appendicular calculus were observed radiologically during a five-year period; before this no case of this disease had been diagnosed (Berg and Berg, 1957).

Differences in interpretation and terminology will also account to some extent for the wide variation in the recorded incidence rates. As already stated there is no sharp dividing line between a heavily calcified faecolith and a true calculus and the final result in any given survey will depend to some extent on which category is chosen for borderline specimens. In this connexion it is interesing to note that Collins, who examined 50,000 appendicectomy specimens over a period of 32 years, makes no mention of calculous disease in his 1955 report. However, he does include in his analysis the finding of calcified faecoliths in 321 specimens, an incidence of $0.64 \%$. Collins must have encountered true calculi in the vast material at his disposal and one assumes that he considered it unnecessary to draw a distinction between calcified faecoliths and true calculi when compiling his very comprehensive analysis. Even so his figure of $0.64 \%$ is surprisingly low for all calcified faecal objects.

It is possible, but unlikely, that the incidence may vary in different countries and localities. It was thought at one stage that the frequency with which appendicular calculi were encountered in the writers' hospital might be related to the high content of chalk in the local soil and drinking water, but it was found that the levels of calcium, phosphorus, phosphatase, and electrolytes in the blood of four patients with the disease were within normal limits, and it is now felt that any geographical variation that might exist is much more likely to be a reflection of the degree of interest shown in the condition from place to place than of any physico-chemical factor.

PRESENT SERIES One thousand eight hundred appendix specimens were sent to the laboratory for examination and from this material 30 specimens were found to contain true calculi as defined previ-

TABLE I

INCIDENCE OF CALCULOUS DISEASE

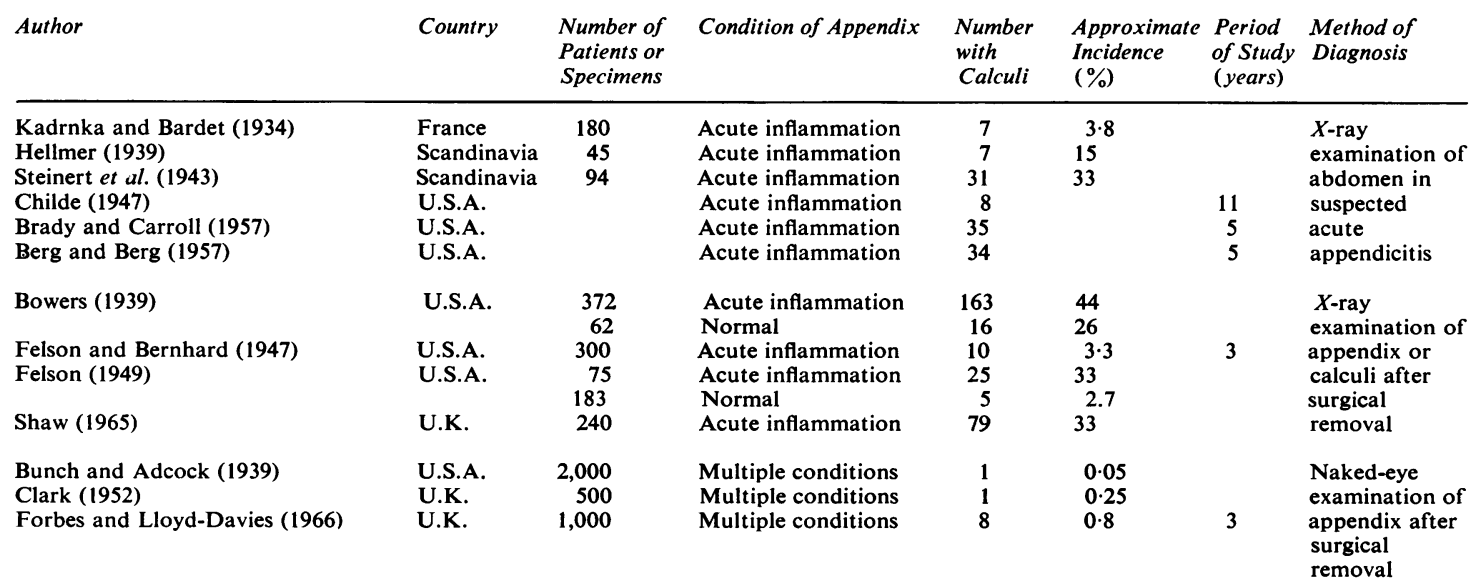


TABLE II

PATTERN OF DISEASE IN 1,800 APPENDICECTOMY SPECIMENS

\begin{tabular}{llc} 
Disease & & $\begin{array}{l}\text { Number } \\
\text { of Specimens }\end{array}$ \\
\hline Inflammation & Acute & 749 \\
& Subacute & 248 \\
& Chronic & 310 \\
Neoplasia & Argentaffinoma & 5 \\
& Secondary carcinoma & 4 \\
& Primary adenocarcinoma & 2 \\
& Adenoma & 1 \\
Miscellaneous & Lymphosarcoma & 1 \\
& Calculi & 30 \\
& Threadworms & 15 \\
& Mucocele & 9 \\
& Melanosis & 3 \\
& Endometriosis & 3 \\
& Fruit seeds & 2 \\
& Lead shot & 2 \\
& Tuberculosis & 1 \\
& Intussusception & 1 \\
& & 444
\end{tabular}

ously (Table II). It should be made clear that the total figure represents only a proportion of the number of appendicectomies performed in the hospital; many specimens, particularly those which were either grossly normal or grossly inflamed, were not submitted for pathological examination during the earlier years of the investigation. During the last three years of the study period, every appendix removed surgically was examined with a view to making a more accurate assessment of the incidence of calculi and other formed faecal objects in routine surgical material. One thousand consecutive specimens were examined and over half of them showed acute or subacute inflammation; the remainder showed no abnormality or low-grade chronic inflammation, usually in the form of fibrosis of the wall of the appendix. One hundred and fifty-four appendices contained faecal objects of which eight were calculi, 44 were calcified faecoliths, and 102 were faecal pellets (Table III).

TABLE III

DETAILS RELATING TO 1,000 CONSECUTIVE APPENDICECTOMY SPECIMENS

\begin{tabular}{lrrrrrr} 
Type of Inclusion & $\begin{array}{c}\text { Number } \\
\text { of Cases }\end{array}$ & \multicolumn{2}{l}{ Inflammation } \\
\cline { 3 - 7 } & & & Acute & Subacute & Chronic & Nil \\
\hline Calculus & 8 & 7 & 1 & 0 & 0 \\
Calcified faecolith & 44 & 41 & 0 & 2 & 1 \\
Faecal pellet & 102 & 41 & 6 & 7 & 48 \\
No inclusion & 846 & 340 & 158 & 155 & 193 \\
Totals & 1,000 & 429 & 165 & 164 & 242
\end{tabular}

The incidence of appendicular calculi relative to other pathological conditions was also determined by analysing the disease encountered in the 1,800 appen- dicectomy specimens. From the tabulated results (Table II), it will be seen that calculous disease occurred much more frequently than such wellknown conditions as mucocele and argentaffinoma.

Shaw (1965) makes the surprising statement that 'stones are formed in the appendix with greater frequency than in either the gall-bladder or the urinary tract, and indeed the appendix is probably the commonest site of stone formation in the body'. We find this opinion quite unacceptable. Our hospital diagnostic records show that during the year 1963 , for example, there were 55 cases of urolithiasis, 99 cases of cholelithiasis, and only three cases of appendicular lithiasis.

AGE AND SEX INCIDENCE According to American reports the majority of patients with appendicular lithiasis were boys and young adult males. Thus in Brady and Carroll's (1957) series half of the patients were children and three-quarters of them were male. In 60 cases reviewed by Felson and Bernhard (1947) most patients were between the ages of 10 and 30 , and there was a male preponderance of nearly $4: 1$. Of Berg and Berg's (1957) 35 patients, 22 were under the age of 15 and there was no significant sex difference. Childe's (1947) eight cases were in the 5 to 12 age group (five male and three female), and in Shaw's series (1965) $56 \%$ were male and $44 \%$ female and no firm conclusion was made as to sex incidence.

There was no significant age trend in the present series, the ages of the 25 patients ranging from 4 to 68 with an average of 29 years. There was a noticeable sex difference, males outnumbering females in the ratio of $2: 1$, but this conforms with the accepted male preponderance in cases of acute appendicitis.

The relatively high incidence among children in the American reports may be related to the more frequent use of radiographs for diagnostic purposes in that age group together with the fact that the thinner abdominal wall in young people may allow poorlycalcified calculi to be detected more readily than calculi of similar density in adults (Clark, 1952).

Thomas (1947) states that the amount of calcium and the degree of hardness are dependent on the age of the faecolith, and he offers this explanation for the relatively soft and poorly-calcified faecolith which he found in his youngest patient, a 6-year-old girl. While this might be true in general, it should be mentioned that two of the hardest stones in the writers' collection were from young children. Kelly (1909) also found a hard, well-calcified faecolith in a child of 3 years.

INCIDENCE IN POST-MORTEM MATERIAL There is very little information on the incidence of calculous disease based on post-mortem material. Felson (1949) 
radiographed 160 'normal' appendices removed at necropsy and detected calcified faecoliths in five $(2.7 \%)$ of them; however, only two $(1.2 \%)$ were considered to contain sufficient calcium to have been visible radiologically in the living body. Bowen (1945) in a 'very limited experience' of post-mortem specimens found two stony-hard calculi in the otherwise normal appendix of a 10-year-old boy. During recent months we have examined 200 appendices in the course of routine post-mortem work; faecal pellets were found occasionally but we failed to find a single calculus or even a calcified faecolith.

\section{DIAGNOSIS}

The great majority of patients with appendicular calculi present as acute abdominal emergencies. Since the calculus will in most cases have lain in the appendix for months or years, gradually increasing in size in a confined space, it is surprising that a history of previous attacks of colicky abdominal pain or of symptoms suggestive of 'grumbling appendix' is seldom given. Eventually the typical picture of acute obstructive appendicitis develops and prompt surgical intervention becomes necessary.

A correct pre-operative diagnosis of appendicular calculus must be a rare event in Britain becjuse of the infrequent use of radiography as an aid to the diagnosis of acute appendicitis. Moreover on those occasions when $x$-ray examination is called for because the diagnosis is in doubt, an opacity on the film caused by an appendicular calculus is liable to be mistaken for some other radio-opaque object, sush as a stone in the right ureter. There is ample evidence from the literature that mistakes of this nature have been made on a number of occasions and the correct diagnosis has come to light only at the time of operation or when the appendix was opened after operation (Prather and Singiser, 1953).

With the increasing use of 'scout' films in acute abdominal surgery it is essential that those who are called on to read $x$-ray films, often under emergency conditions, should be familiar with the radiological features of appendicular calculi. They occur characteristically as single or multiple opacities in the right lower abdominal quadrant, and are usually rounded or ovoid, with smooth outlines, measuring up to $3 \mathrm{~cm}$. in diameter (Fig. 2). When multiple they tend to lie in a slightly curved line and may show faceting (Fig. 3a and b). A feature of diagnostic value is wellmarked lamination with relative translucency of the central part (Fig. 4); mobility, when present, is also a useful diagnostic sign. Other opacities which enter into the differential diagnosis are those caused by gallstones, either in a low-lying gall-bladder or impacted in the terminal ileum, urinary calculi in the

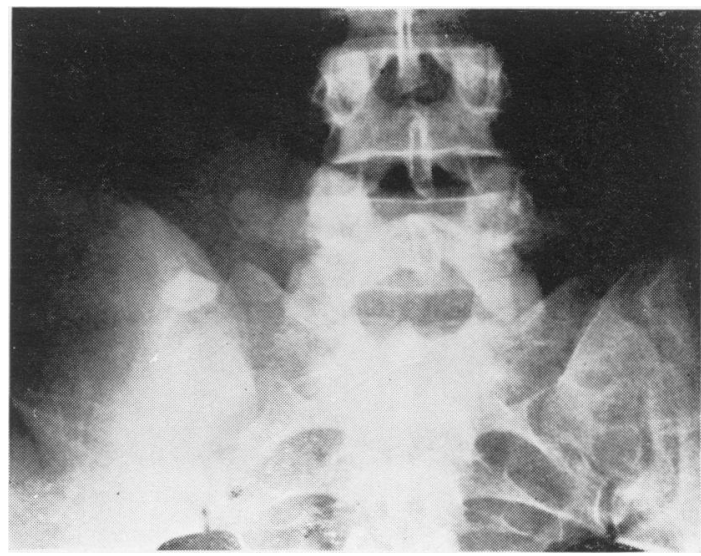

FIG. 2. Case 25. Radisgraph of abdomen showing appendicular calculus overlying upper part of right sacro-iliac joint.

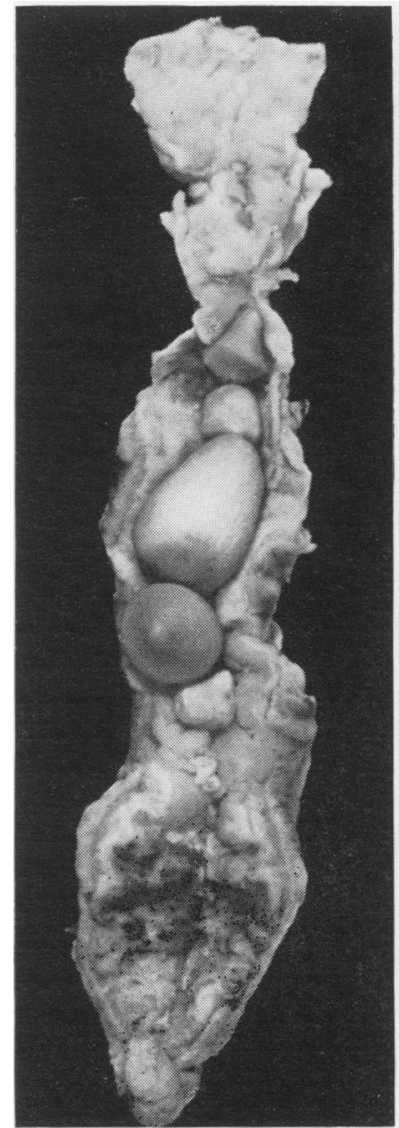

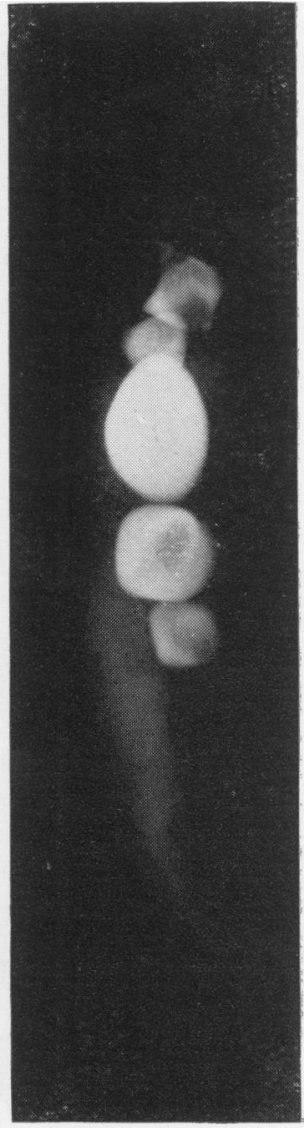

b
FIG. 3. Case 1. Five faceted calculi in operation specimen (a) (actual size), and (b) radiograph of specimen. 


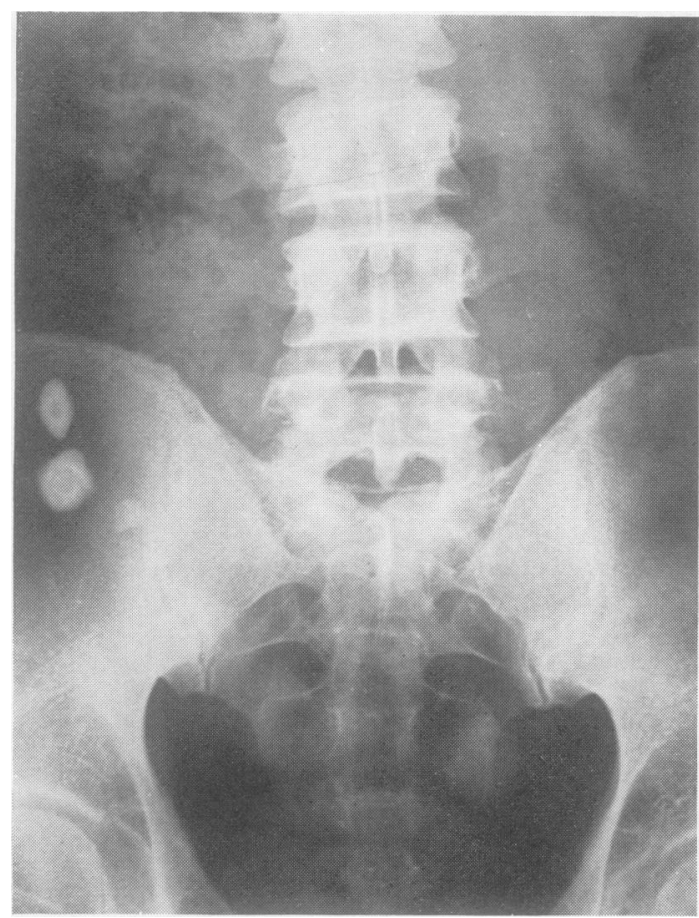

FIG. 4. Case 13. Radiograph of abdomen showing three radio-opaque appendicular calculi.

lower pole of the right kidney, right ureter, or bladder, calcified mesenteric lymph nodes, and phleboliths. Ureteric calculus is the condition most likely to cause confusion in an acute abdominal emergency; the stone in this case will lie in the line of the ureter and is unlikely to show lamination. Examination of the urine for blood and, if necessary, an intravenous or retrograde pyelogram, will help to establish the correct diagnosis. A gallstone causing acute ileal obstruction will be larger than an appendicular stone and less densely calcified; moreover biliary calculi will probably be seen in the gall-bladder area and air may be present in the biliary ducts. The age and sex of the patient might also help to differentiate these two conditions since appendicular stones, unlike gallstones, occur most frequently in young males. Calcified mesenteric glands usually occur in groups and are of mottled uneven opacity, while phleboliths are smaller, rounded, and of more homogeneous opacity.

The identification of appendicular calculi found in operation specimens should present no difficulty to those familiar with the appearance of these objects, but even experienced surgeons and pathologists will sometimes make the error of mis-identifying them as gallstones, especially when the calculi are multiple and faceted. Theoretically small biliary or pancreatic calculi may enter the intestinal tract and find their way into the appendix, but this must be a very rare occurrence. The features which serve to distinguish true appendicular calculi from calculi in the appendix of extrinsic derivation, if such ever occurs, are their size and composition. The majority of appendix stones have a minimal diameter greater than the orifice of the appendix, a point strongly in favour of an intrinsic origin, and their main chemical component is calcium phosphate, a mineral seldom found in gallstones.

\section{COMPLICATIONS}

Wangensteen and Bowers (1937), Bowen (1943), and other authors have drawn attention to the aetiological role of faecoliths in the production of acute appendicitis. It is generally agreed that these objects are the most frequent cause of the obstructive type of appendicitis, a type which is particularly liable to progress to gangrene and perforation (Fig. 5). These

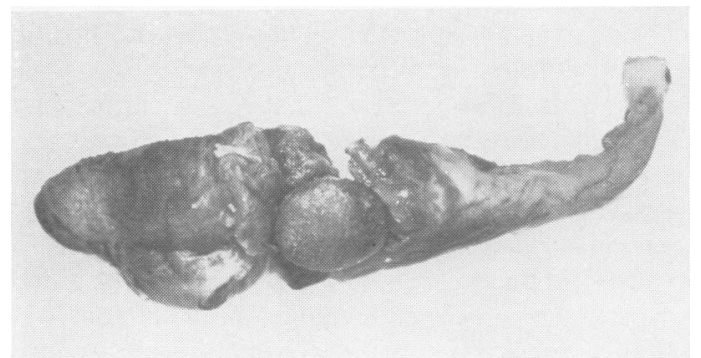

FIG. 5. Case 2. Operation specimen showing calculus and perforation (actual size).

complications develop in consequence of the blood supply being impaired from blockage and distension of the lumen. In some cases pressure necrosis will occur in the wall at the site of the faecolith, especially if the latter is hard and calcified, with subsequent perforation of the organ, and it is not surprising, therefore, that the incidence of gangrene and/or perforation in cases of calculous appendicitis is strikingly high. Felson and Bernhard (1947) state that $90 \%$ of the appendices were acutely inflamed and that perforation had occurred in nearly $50 \%$. Berg and Berg (1957) record a $48 \%$ incidence of gangrene or perforation, while Brady and Carroll (1957) make the remarkable claim that all but two of the appendices in their series of 34 cases had perforated. In the present study 12 of the calculus-containing appendices were gangrenous (Fig. 6) and three more had perforated giving a combined gangrene/perforation incidence of $50 \%$. The frequency with which calculi or calcified faecoliths are found in cases of 


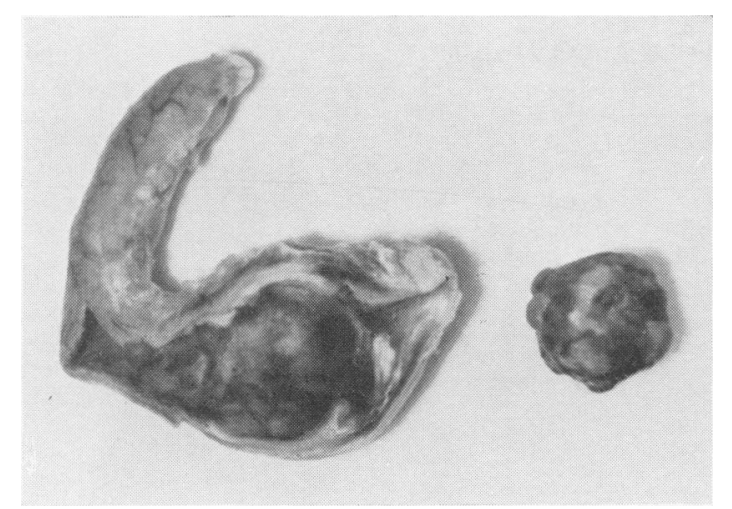

FIG. 6. Case 12. Operation specimen (actual size).

appendicitis with perforation may even be higher than that recorded because a calcified object lying free in the peritoneal cavity or in an appendix abscess may be missed at operation. Later it may be extruded through the operation wound as happened in the case reported by Wells (1930). It would seem too that the degree of morbidity is roughly proportional to the amount of calcification. Thus in the 1,000 consecutive appendicectomy specimens already referred to it was found that six of the eight calculi and all but three of the 44 calcified faecoliths were associated with a severe, acute inflammation, whereas over half of the appendices containing non-calcified faecal pellets showed only low-grade chronic inflammation or no abnormality at all (Table III). As non-calcified faecal pellets were found with almost equal frequency in normal and inflamed appendices, the part played by these objects in the aetiology of acute appendicitis is probably not significant, at any rate while they remain uncalcified. Moreover only $20 \%$ of acutely inflamed appendices in our material contained formed faecal objects, indicating that some other factor or combination of factors is responsible for initiating the disease process in most cases of acute inflammation. Nevertheless we agree with other observers that the presence of an inclusion, especially one which is calcified, plays an important aetiological role in a proportion of cases of appendicitis.

A rare complication of appendicular calculus is the formation of a fistula between the appendix and some part of the intestine. Kjellman (1957) reported two cases of intestinal fistula caused by calculi. In one patient a gangrenous appendix, which contained two calculi, was adherent at the tip to the descending part of the duodenum causing a fistula between the two organs. The other patient had a fistula between the appendix and the ileum and a stone at the tip of the appendix could be pushed through the orifice of the fistula so that it projected into the ileum. Thomas (1947) reported a case of fistula between the appendix and the caecum caused by a calcified coprolith which was found in an abscess adjacent to the fistula. A further rare complication is the formation of a traction diverticulum of the bladder in association with an abscess secondary to calculous appendicitis (Fox, 1962).

The damage caused to the mucosa of the appendix by a rough hard calculus may provide a portal of entry for many pathogenic bacteria. When the trauma is associated with local gangrene the conditions are then ideal for the entry and multiplication of anaerobic organisms, including faecal-borne Actinomyces. Steinert et al. (1947) operated on a patient with a radiologically visible calculus in the appendix and found at operation a peri-appendicular actinomycotic infiltration. A case with similar features was encountered during this study (case 25).

\section{PHYSICAL CHARACTERS OF THE CALCULI}

The main physical and radiological characters of appendicular calculi have been described and illustrated already; it remains to discuss briefly certain additional features relating to their size, number, weight, and composition (Table IV).

In the present series two-thirds of the specimens contained solitary stones; when multiple the calculi numbered up to seven in an appendix. From published reports this would seem to be about the usual numerical distribution. However, Shahan (1940) reported 23 in one appendix, and 16 were found in the appendix of Thomas's second case (1947). The largest calculus is that recorded by Packard (1921); it measured $4 \times 2 \times 1 \mathrm{~cm}$. and weighed $8 \mathrm{~g}$. This weight is exceeded by the calculus described by Bunch and Adcock (1939) which, although somewhat smaller, weighed $13.5 \mathrm{~g}$. Others to record 'giant' calculi are Wells (1930), Pilcher (1945), Lowenberg (1949), and Chapple (1951); the latter reported two cases in middle-aged patients, the stones weighing $8 \mathrm{~g}$. and $5 \mathrm{~g}$. Several moderately large stones were seen during the present study; only three specimens were weighed and the largest of these (but not the largest in the collection) measured $2 \mathrm{~cm}$. in main diameter and weighed $2.07 \mathrm{~g}$. These stones were weighed in the dry state a few days or weeks after removal and it is probable that the relatively low weights obtained were due to desiccation.

In 1921 Maver and Wells analysed 25 appendicular concretions and found calcium phosphate, fatsoluble substances (coprosterol, cholesterol, soaps), and organic matter in the proportion of $25 \%, 50 \%$, and $20 \%$ respectively. Atwell and Pollock (1960), who regard stony-hard appendicular calculi as falling 
TABLE IV

DETAILS OF 30 CASES OF APPEND:CULAR LITHIASIS ${ }^{1}$

\begin{tabular}{|c|c|c|c|c|c|c|c|c|c|c|c|c|}
\hline \multirow[t]{2}{*}{ Case No. } & \multirow[t]{2}{*}{ Reference } & \multirow[t]{2}{*}{ Sex } & \multirow[t]{2}{*}{ Age } & \multicolumn{6}{|l|}{ Calculi } & \multirow{2}{*}{$\begin{array}{l}\text { Inflammation } \\
\text { of Appendix }\end{array}$} & \multirow{2}{*}{$\begin{array}{l}\text { Blood } \\
\text { Chemistry }\end{array}$} & \multirow{2}{*}{$\begin{array}{l}\text { Figure } \\
\text { No. }\end{array}$} \\
\hline & & & & Number & Colour & Shape & $\begin{array}{l}\text { Size } \\
(\mathrm{mm} .)\end{array}$ & $\begin{array}{l}\text { Weight } \\
(\text { g. })\end{array}$ & Composition & & & \\
\hline 1 & L.R. & $\mathbf{F}$ & 53 & 5 & $\begin{array}{l}\text { Reddish } \\
\text {-brown }\end{array}$ & $\begin{array}{l}\text { Ovoid and } \\
\text { faceted }\end{array}$ & $\begin{array}{l}17 \times 10 \\
\text { (largest) }\end{array}$ & & $\begin{array}{l}\text { Calcium } \\
\text { phosphate }\end{array}$ & $\begin{array}{l}\text { Acute with } \\
\text { gangrene }\end{array}$ & & $3 a$ and $b$ \\
\hline 2 & N.S. & $\mathbf{F}$ & 44 & 1 & $\begin{array}{l}\text { Mottled } \\
\text { brown }\end{array}$ & Ovoid & $18 \times 14$ & 1.74 & $\begin{array}{l}\text { Calcium } \\
\text { phosphate }\end{array}$ & $\begin{array}{l}\text { Acute with } \\
\text { perforation }\end{array}$ & & 5 \\
\hline 3 & G.P. & $\mathbf{M}$ & 32 & 2 & $\begin{array}{l}\text { Brownish } \\
\text { black }\end{array}$ & Rounded & $\begin{array}{r}10 \\
4\end{array}$ & $\begin{array}{l}0.5 \\
\text { (largest) }\end{array}$ & $\begin{array}{l}\text { Calcium } \\
\text { phosphate }\end{array}$ & $\begin{array}{l}\text { Acute with } \\
\text { gangrene }\end{array}$ & & $1 \mathrm{~b}$ \\
\hline 4 & J.C. & $\mathbf{M}$ & 53 & 1 & Black & Nodular & 20 & 2.07 & $\begin{array}{l}\text { Calcium } \\
\text { phosphate }\end{array}$ & Subacute & & \\
\hline 5 & M.C. & $\mathbf{F}$ & 34 & 1 & $\begin{array}{l}\text { Pale, } \\
\text { speckled }\end{array}$ & Elliptical & $32 \times 13 \times$ & & & $\begin{array}{l}\text { Acute with } \\
\text { perforation }\end{array}$ & & \\
\hline 6 & P.B. & $\mathbf{M}$ & 20 & 3 & $\begin{array}{l}\text { Pale } \\
\text { brown }\end{array}$ & Irregular & & & & $\begin{array}{l}\text { Acute with } \\
\text { gangrene }\end{array}$ & $\begin{array}{l}\text { Ca } 9 \cdot 5 \text { P } 4 \cdot 7 \\
\text { Alk phos } 6 \cdot 3\end{array}$ & \\
\hline 7 & M.S. & $\mathbf{M}$ & 18 & 1 & $\begin{array}{l}\text { Dark } \\
\text { brown }\end{array}$ & Rounded & 3 & & & Acute & & \\
\hline 8 & W.H. & $\mathbf{M}$ & 41 & 4 & $\begin{array}{l}\text { Reddish } \\
\text { brown }\end{array}$ & Irregular & 6 & & & $\begin{array}{l}\text { Acute with } \\
\text { gangrene }\end{array}$ & & \\
\hline 9 & A.H. & $\mathbf{M}$ & 43 & 1 & $\begin{array}{l}\text { Dark } \\
\text { brown }\end{array}$ & Ovoid & $18 \times 11$ & & & $\begin{array}{l}\text { Acute with } \\
\text { gangrene }\end{array}$ & $\begin{array}{l}\text { Ca } 10 \text { P } 4 \\
\text { Alk phos } 12\end{array}$ & \\
\hline 10 & F.B. & $\mathbf{M}$ & 20 & 5 & $\begin{array}{l}\text { Buff to } \\
\text { dark } \\
\text { brown }\end{array}$ & $\begin{array}{l}\text { Rounded } \\
\text { (1 } \\
\text { spiculated) }\end{array}$ & $\begin{array}{l}14 \\
\text { (largest) }\end{array}$ & & & $\begin{array}{l}\text { Acute with } \\
\text { gangrene }\end{array}$ & & \\
\hline 11 & C.C. & $\mathbf{F}$ & 13 & 1 & $\begin{array}{l}\text { Pale } \\
\text { brown }\end{array}$ & Ovoid & $14 \times 10 \times$ & & & $\begin{array}{l}\text { Acute with } \\
\text { gangrene }\end{array}$ & & \\
\hline 12 & R.V. & $\mathbf{M}$ & 24 & 1 & $\begin{array}{l}\text { Reddish- } \\
\text { brown }\end{array}$ & Rounded & 17 & & & $\begin{array}{l}\text { Acute with } \\
\text { gangrene }\end{array}$ & & \\
\hline 13 & L.H. & $\mathbf{M}$ & 42 & 4 & $\begin{array}{l}\text { Pale to } \\
\text { reddish } \\
\text { black }\end{array}$ & $\begin{array}{l}\text { Ovoid and } \\
\text { diamond }\end{array}$ & $\begin{array}{l}20 \\
\text { (largest) }\end{array}$ & & & Acute & & \\
\hline 14 & R.S. & $\mathbf{M}$ & 14 & 2 & Brown & Irregular & 4 & & & $\begin{array}{l}\text { Acute with } \\
\text { gangrene }\end{array}$ & & \\
\hline 15 & K.D. & $\mathbf{F}$ & 68 & 1 & Brown & Ovoid & $4 \times 2$ & & & $\begin{array}{l}\text { Acute with } \\
\text { gangrene }\end{array}$ & & \\
\hline 16 & H.W. & $\mathbf{M}$ & 59 & 1 & $\begin{array}{l}\text { Dark } \\
\text { brown }\end{array}$ & Round & 6 & & & Chronic & & \\
\hline 17 & R.K. & $\mathbf{M}$ & 14 & 1 & $\begin{array}{l}\text { Grey- } \\
\text { black }\end{array}$ & Rounded & 7 & & & Acute & & \\
\hline 18 & N.M. & $\mathbf{M}$ & 7 & 1 & $\begin{array}{l}\text { Mottled, } \\
\text { light and } \\
\text { dark brown }\end{array}$ & Ovoid & $16 \times 8$ & & & Acute & & \\
\hline 19 & G.D. & $\mathbf{M}$ & 4 & 4 & $\begin{array}{l}\text { Light } \\
\text { brown }\end{array}$ & $\begin{array}{l}\text { Rounded } \\
\text { and } \\
\text { ovoid }\end{array}$ & Up to 6 & & & $\begin{array}{l}\text { Acute with } \\
\text { gangrene }\end{array}$ & & \\
\hline 20 & R.W. & 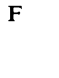 & 50 & 7 & $\begin{array}{l}\text { Dark } \\
\text { brown to } \\
\text { black }\end{array}$ & $\begin{array}{l}\text { Rhomboid } \\
\text { and ovoid }\end{array}$ & Up to 8 & & & $\begin{array}{l}\text { Acute with } \\
\text { perforation }\end{array}$ & $\begin{array}{l}\text { Ca 9.4 P 2.6 } \\
\text { Alk phos } 7\end{array}$ & \\
\hline 21 & W.B. & $\mathbf{M}$ & 22 & 1 & $\begin{array}{l}\text { White and } \\
\text { brown }\end{array}$ & Ovoid & $8 \times 7 \times 5$ & & & Acute & & \\
\hline 22 & R.C. & $\mathbf{M}$ & 6 & 1 & $\begin{array}{l}\text { Dark } \\
\text { brown }\end{array}$ & Irregular & 3 & & & Acute & & \\
\hline 23 & L.S. & $\mathbf{M}$ & 10 & 1 & $\begin{array}{l}\text { Brown } \\
\text { and black }\end{array}$ & Ovoid & 10 & & & Acute & & \\
\hline 24 & H.P. & $\mathbf{F}$ & 5 & 1 & $\begin{array}{l}\text { Mottled } \\
\text { brown }\end{array}$ & Ovoid & 8 & & & Acute & & \\
\hline 25 & P.B. & $F$ & 26 & 1 & & Ovoid & $17 \times 7$ & & & Actinomycosis & & \\
\hline 26 & K.M. & $\mathbf{M}$ & 22 & 1 & $\begin{array}{l}\text { Pale } \\
\text { brown }\end{array}$ & Triangular & 7 & & & Chronic & & \\
\hline 27 & M.G. & $\mathbf{F}$ & 26 & 1 & $\begin{array}{l}\text { Pale } \\
\text { brown }\end{array}$ & Irregular & 6 & & & $\begin{array}{l}\text { Acute with } \\
\text { gangrene }\end{array}$ & & \\
\hline 28 & E.S. & $\mathbf{M}$ & 9 & 1 & $\begin{array}{l}\text { Pale } \\
\text { brown }\end{array}$ & $\begin{array}{l}\text { Pear- } \\
\text { shaped }\end{array}$ & 35 & & & Acute & & \\
\hline 29 & P.M. & $\mathbf{F}$ & 48 & 1 & $\begin{array}{l}\text { Dark } \\
\text { brown, } \\
\text { shiny }\end{array}$ & Ovoid & 5 & & & Chronic & & \\
\hline 30 & R.W. & $\mathbf{M}$ & 53 & 2 & White & Rounded & 15 & & & Acute & & \\
\hline & & & & & $\begin{array}{l}\text { Dark } \\
\text { brown, } \\
\text { shiny }\end{array}$ & Rounded & 5 & & & & & \\
\hline
\end{tabular}

${ }^{1}$ Of 30 patients ( 20 male, 10 female) aged 4 to 68 years, 20 were found to have single calculi at operation, and 10 multiple calculi. The calculi varied in size between 3 and $35 \mathrm{~mm}$. and weighed up to $2.07 \mathrm{~g}$. The appendix was acutely inflamed in 25 cases, subacutely in two, and chronically in three. 
within the group of true calcium enteroliths of primary endogenous origin, found a much higher proportion $(90 \%)$ of calcium salts in the few calculi which they examined. This finding is in accord with our experience; calculi from four patients in the present series were analysed and all were found to consist almost entirely of calcium phosphate. It should be added, however, that, in order to preserve the calculi for the museum, only a portion of each stone was removed for analysis, and that from the periphery where the calcium content is likely to have been maximal.

\section{SUMMARY AND CONCLUSIONS}

Two thousand appendices were examined for evidence of calculous disease. One thousand eight hundred were specimens removed surgically and 29 of them harboured stony-hard calculi. The incidence of calculous disease in 1,000 consecutive appendicectomy specimens was $0.8 \%$. An additional calculus was observed radiologically in a case of appendicular actinomycosis.

All but five of the 30 calculus-containing appendices were acutely inflamed and $50 \%$ of these were gangrenous or perforated. Others have reported fistula formation as a complication of calculous disease.

Two hundred appendices were examined during routine post-mortem work and on no occasion was a calculus found.

Discrepancies between the findings of various workers, particularly in relation to the incidence and composition of appendicular calculi, were noted during this study. All of these can be traced to differences in the selection of material and in the criteria and terminology used for classifying calcified appendicular inclusions. What constitutes a true calculus as opposed to a calcified faecolith or concretion is of little more than academic interest; from the practical viewpoint, it is important to realize that the presence of a calcified object within the appendix, call it what you will, is likely to lead, sooner or later, to dangerous complications. Early surgical treatment is therefore indicated when an appendicular calculus is revealed, by intention or chance, on radiological examination of the abdomen.

We are greatly indebted to the surgical staff of Kent and Canterbury Hospital for allowing us access to their case notes. Mr. R. L. Canney, M.Ch., F.R.C.S. and Dr. S. J. Johnson, M.B., D.M.R.D., kindly read through the paper and made helpful suggestions. We are also very grateful to Mr. E. Spice, F.I.M.L.T., for preparing the photographs and to Miss K. Thurgood and Miss M. Hawkins for clerical assistance.
REFERENCES

Airth, G. R. (1948). Appendiceal calculus. Brit. J. Radiol., 21, 526-527. Atwell, J. D., and Pollock, A. V. (1960). Intestinal calculi. Brit. J. Surg., 47, 367-374.

Berg, R. M., and Berg, H. M. (1957). Coproliths. Radiology, 68, 839 844.

Bowen, W. H. (1943). The aetiology of appendicitis. Brit. J. Surg., 31, 127-135.

- (1945). Obstructive appendicitis. Ibid., 32, 468-471.

Bowers, W. F. (1939). Aprendicitis with especial reference to pathogenesis, bacteriology and healing. Arch. Surg., 39, 362-422.

Brady, B. M. and Carroll, D, S. (1957). The significance of the calcified appendiceal enterolith. Radiology, 68, 648-653.

Bunch, G. H., and Adcock, D. F. (1939). Giant faceted calculus of the appendix. Ann. Surg. 109, 143-146.

Butler, M. F. (1959). Appendicular calculi. Brit. J. Surg., 47, 279-281.

Candy, J. (1959). Appendiceal calculi. Ibid., 47, 192-195.

Chapple, C. F. (1951). Appendicea calculi. A report of 2 cases and a brief review of the literature. Brit. J. Surg., 38, 503-506.

Childe, A. E. (1947). Calcified appendiceal fecal concretions in childhood: a report of 8 cases. Amer. J. Roentgenol., 58, 455-463.

Clark, L. P. (1952). Calculi in the appendix. Brit. J. Surg., 40, 272-273.

Collins, D. C. (1931). Historic phases of appendicitis. Ann. Surg., 94, 179-196.

- (1955). A Study of 50,000 specimens of the human vermiform appendix. Surg. Gynec. Obstet., 101, 437-445.

Felson, B. (1949). Appendica calculi: incidence and clinical significance Surgery, 25, 734-737.

Felson, B., and Bernhard, C. M. (1947). The roentgenologic diagnosis of appendiceal calculi. Radiology, 49, 178-191.

Fittig, O. (1907). Die Bedentung der Enterolithen des Processus vermiformis im Röntgenogramm. Fortschr. Röntgenstr., 11, 356. (Quoted by Laforet et al., 1951).

Fox, M. (1962). Appendix abscess with stone formation and traction diverticulum of bladder. Brit. med. J., 2, 1731-1732.

Graham, C., and Guthrie, D. (1911). The dyspeptic type of chronic appendicitis (pyloric spasm) with differential diagnosis. Coll. pap. Mayo Clin., 2, 225-234. (Quoted by Prather and Singiser, 1953).

Hancock, H. (1848). Disease of the appendix caeci cured by operation. Lancet, 2, 380-382.

Hellmer, H. (1939). Röntgenundersökning av akuta bukoch njurfall. Nord. Med., 3, 2891-2896.

Kadrnka, S., and Bardet, P. (1934). L'appendicite calculeuse. J. Radiol. Electrol., 18, 515-530 (Quoted by Felson, 1949).

Kelly, H. A. (1909). Appendicitis and Other Diseases of the Vermiform Appendix, p. 22, Lippincott, Philadelphia.

Kjellman, T. (1957). Appendiceal fistulae and calculi: review of the literature and a report of 3 cases. Acta chir. scand., 113, 123-139.

Laforet, E. G., Greenler, J. J., and O'Brien, E. J., Jr. (1951). Acute appendicitis with radiopaque appendiceal lithiasis. Amer. J. Roentgenol., 65, 867-877.

Levi, D. (1934). A radiopaque concretion in the appendix. Lancet, 2, 653-654.

Lowenberg, R. I. (1949). Appendiceal calculi: their pathologic and clinical significance. Ann. Surg., 130, 975-979.

Maver, M. E., and Wells, H. G. (1921). The composition of appendicea concretions. Arch. Surg., 3, 439-444.

Meyerowitz, B. R. (1960). Appendicular calculi. Brit. J. Radiol., 33, 631-633.

Moloney, G. E. (1947). Acute appendicitis simulating gall-stone ileus. Brit. J. Surg., 35, 212-213.

Packard, H. (1921). Appendicular lithiasis. Report of a case unique in the annals of surgery. Boston med. surg. J., 185, 656-657.

Pilcher, L. S. (1945). Giant calculus of the appendix. New Engl. J. Med., 232, 163-165.

Prather, G. C., and Singiser, J. A. (1953). The urological importance of radiopaque appendiceal concretions. J. Urol. (Baltimore), 69, 714-720.

Roux, J. (1913). De l'emploi des rayons $\mathrm{X}$ avant l'appendicectomie. Clin. Chir. de L'Universite de Lausanne, $49 \mathrm{pp}$. (Quoted by Collins, 1931).

Santorini, G. D. (1742). (Quoted by Collins, 1931). Ann. Surg., 94, 180.

Seelig, M. G. (1908). Appendicitis resembling ureteral calculus. Surg. Gynec. Obstet., 7, 485-486.

Shahan, J. (1940). An unusual case of multiple appendiceal lithiasis. Radiology, 35, 89-90. 
Shaw, R. E. (1965). Appendix calculi and acute appendicitis. Brit. J. Surg., 52, 451-459.

Smith, S. M. (1954). Appendiceal calculus: a report on 4 cases. Brit. J. Radiol., 27, 187-188.

Steinert, R., Hareide, I., and Christiansen, T. (1943). Roentgenologic examination of acute appendicitis. Acta radiol. (Stockh.), 24, 13-37.

Thomas, S. F. (1947). Appendiceal coproliths: their surgical importance. Radiology, 49, 39-49.
Wangensteen, O. H., and Bowers, W. F. (1937). Significance of the obstructive factor in the genesis of acute appendicitis. Arch. Surg., 34, 496-526.

Wegeler, F. (1813). Historia enteritidis malignae et singularis calculosi concrementi. J. Méd. Chir. Pharm., 28, 384-391. (Quoted by Collins 1931).

Weisflog (1906). Zur röntgenographischen Diagnose der Enterolithen des Processus vermiformis. Fortschr. Röntgenstr., 10, 217-219.

Wells, C. A. (1930). Appendix concretions opaque to $\mathrm{X}$ rays. Brit. med. J., 2, 1041-1042. 